\title{
Produksi Rumput Gajah (Pennisetum purpureum) yang Diberi Pupuk N, P dan K dengan Dosis 0, 50 dan 100\% pada Devoliasi Hari ke-45
}

\author{
Daniel Yohanis Seseray ${ }^{1}$, Budi Santoso ${ }^{2}$ dan Marlyn Nelce Lekitoo ${ }^{2}$ \\ ${ }^{1}$ Jurusan Produksi Ternak, Universitas Negeri Papua, Manokwari 98314 \\ ${ }^{2}$ Jurusan Nutrisi dan Makanan Ternak, Universitas Negeri Papua, Manokwari 98314
}

\begin{abstract}
ABSTRAK
Produksi rumput gajah (Pennisetum purpureum) akan lebih baik bila dilakukan pemupukan dengan dosis yang tepat dan sesuai. Penelitian ini bertujuan untuk mengetahui produksi segar, bahan kering, rasio batang dan daun, kandungan bahan kering dan bahan organik rumput gajah yang di berikan pupuk N, $\mathrm{P}$ dan $\mathrm{K}$ dengan dosis $0 \%, 50 \%$ dan $100 \%$ pada defoliasi hari ke- 45 setelah tanam. Penelitian ini menggunakan metode eksperimen dengan rancangan acak kelompok yang terdiri dari 5 kelompok dan 3 perlakuan, sehingga terdapat 15 satuan percobaan. Perlakuan yang digunakan adalah; Perlakuan 1 (kontrol/tanpa pupuk), Perlakuan 2 (100 kg Urea/ha : $50 \mathrm{~kg}$ TSP $/ \mathrm{ha}: 50 \mathrm{~kg} \mathrm{KCL} / \mathrm{ha})$ dan Perlakuan 3 (200 kg Urea/ha : $100 \mathrm{~kg}$ TSP/ha : $100 \mathrm{~kg} \mathrm{KCL} / \mathrm{ha})$. Hasil penelitian menunjukkan bahwa perlakuan dosis pemupukan tidak berpengaruh nyata $(\mathrm{P} \geq 0,05)$ terhadap produksi segar, bahan kering, rasio batang:daun, kandungan bahan kering dan bahan organik rumput gajah pada umur defoliasihari ke-45. Perlakuan 2 dan 3 meningkatkan produksi segar rumput gajah masing-masing 29,86\% dan $28,51 \%$, sedangkan produksi bahan kering masing-masing $28,85 \%$ dan $30,77 \%$ dibandingkan perlakuan 1 (kontrol). Rasio batang dan daun rumput gajah bervariasi antara 59,01 - 61,26\% : 38,07 $40,09 \%$. Kandungan bahan organik cenderung meningkat seiring peningkatan dosis pupuk N, P dan K.
\end{abstract}

Kata kunci : produksi rumput gajah, pupuk N, P, dan K, dosis pupuk

\section{Production of Elephant Grass (Pennisetum purpureum) Provided Fertilizer $N, P$, and $K$ the Doses 0, 50 and 100\% at Defoliation $45^{\text {th }}$ Day}

\begin{abstract}
Production of elephant grass (Pennisetum purpureum) would be better if fertilized with the proper doses and appropriate. This study aimed to determine the production of fresh matter, dry matter, ratio of grass stems and leaves, dry matter and organic matter of elephant grass given fertilizer $N, P$ and $K$ with the doses of $0 \%, 50 \%$ and $100 \%$ at defoliation at $45^{\text {th }}$ day. This study used an experimental method of randomized block design experiment consisted of 5 and 3 treatments groups, so there were 15 experimental units. The treatments used were: Treatment 1 (control/not fertilizer), Treatment 2 (100 kg Urea/ha; $50 \mathrm{~kg} \mathrm{TSP} / \mathrm{ha} ; 50 \mathrm{~kg} \mathrm{KCl/ha)}$ and Treatment 3 (200 kg Urea/ha, $100 \mathrm{~kg} \mathrm{TSP} / \mathrm{ha}: 100 \mathrm{~kg} \mathrm{KCl} / \mathrm{ha}$ ). The results showed that the doses of fertilization treatments did not significantly $(P \geq 0,05)$ affect the fresh matter, dry matter, ratio of grass stems:leaves, dry matter and organic matter value of elephant grass at the first harvest aged $45^{\text {th }}$ day. Treatment 2 and 3 increased forage the fresh matter production by $29.86 \%$ and $28.51 \%$, respectively, while production of dry matter by $28.85 \%$ and $30.77 \%$ compared to treatment 1 (control). The ratio of grass stems and leaves varied between 59.1 - 61.26\%:38,7 - 40, 9\%. Organic matter content tended to increase with increasing doses of $N, P$ and $K$ fertilizer.
\end{abstract}

Key words : elephant grass production, $N, P$, and $K$ fertilizer, fertilizer doses 


\section{PENDAHULUAN}

Ketersediaan pakan khususnya pakan hijauan baik kualitas, kuantitas maupun kontinuitasnya merupakan faktor yang penting dalam menentukan keberhasilan usaha peternakan ternak ruminansia. Hal ini disebabkan hampir 90\% pakan ternak ruminansia berasal dari hijauan dengan konsumsi segar perhari $10-15 \%$ dari berat badan, sedangkan sisanya adalah konsentrat dan pakan tambahan (feed supplement) (Sirait et al., 2005).

Kendala dalam penyediaan pakan hijauaan yang berkualitas dan berkelanjutan adalah lahan subur atau produktif untuk penanaman pakan hijauan ternak, karena penggunaan lahan produktif biasanya digunakan untuk tanaman bernilai ekonomis tinggi. Salah satu solusi untuk mengatasi masalah tersebut adalah dengan pemanfaatan lahan-lahan marjinal atau kurang produktif dengan pemberian unsur hara yang diperlukan tanaman dengan cara pemupukan yang sesuai dengan kebutuhan tanaman (Fanindi et al., 2005).

Sajimin et al. (2001) menyatakan bahwa untuk memperoleh produksi yang tinggi pada lahan yang tingkat kesuburannya rendah dapat dilakukan dengan penggunaaan pupuk organik. Penyediaan unsur hara terutama nitrogen $(\mathrm{N})$, pospof $(\mathrm{P})$, dan kalium (K) dalam tanah secara optimal bagi tanaman dapat meningkatkan produksi tanaman. Disamping upaya penyediaan unsur hara perlu juga dilakukan pemilihan jenis hijauan unggul yang cocok dan responsif terhadap pemupukan.

$$
\text { Rumput gajah (Pennisetum }
$$
purpureum) merupakan tanaman pakan ternak yang sangat responsif terhadap pemupukan berat yaitu pada dosis 40 ton pupuk kandang/ha/tahun, $\quad 800$ $\mathrm{kg} / \mathrm{urea} / \mathrm{ha} / \mathrm{tahun}, 200 \mathrm{~kg} \mathrm{KCl} / \mathrm{ha} /$ tahun dan $200 \mathrm{~kg} \mathrm{TSP} / \mathrm{ha} /$ tahun (Lugiyo dan Sumarto, 2000). Rumput gajah juga sebagai tanaman konservasi lahan, terutama di daerah bertopografi pegunungan dan berlereng (Prasetyo, 2003) dan sumber bioethanol (Sari, 2009).
Adiati et al. (1995) menyatakan bahwa pertumbuhan dan produksi rumput gajah di Indonesia sangat bervariasi. Pertumbuhan dan produksi rumput ini akan lebih baik bila dilakukan pemupukan dengan dosis yang tepat dan sesuai. Penggunaan dosis pupuk $\mathrm{N}$, $\mathrm{P}$, dan $\mathrm{K}$ secara optimal dapat meningkatkan produksi rumput gajah. Oleh karenanya diperlukan suatu penelitian dengan tujuan untuk mengetahui produksi rumput gajah yang meliputi produksi bahan segar, produksi bahan kering, rasio batang:daun, kandungan bahan kering dan bahan organik rumput gajah yang di berikan pupuk N, P dan K dengan dosis berbeda.

\section{METODE PENELITIAN}

Penelitian ini dilaksanakan di Taman Ternak Fakultas Peternakan Perikanan dan Ilmu Kelautan Universitas Negeri Papua Manokwari, selama tiga bulan. Bahan dan alat yang digunakan dalam penelitian ini adalah air, stek rumput gajah, pupuk $\mathrm{N}$ (Urea), P (TSP), dan K (KCl).

Penelitian ini menggunakan metode eksperimen dengan Rancangan Acak Kelompok (RAK) yang terdiri dari 5 kelompok dan 3 perlakuan, sehingga terdapat 15 satuan percobaan. Perlakuan yang digunakan dalam penelitian adalah: perlakuan 1 (kontrol/tanpa pupuk), perlakuan 2 (100 kg Urea/ha : $50 \mathrm{~kg} \mathrm{TSP} / \mathrm{ha}$ : $50 \mathrm{~kg} \mathrm{KCL} / \mathrm{ha})$ dan perlakuan $3(200 \mathrm{~kg}$ Urea/ha : $100 \mathrm{~kg} \mathrm{TSP} / \mathrm{ha}: 100 \mathrm{~kg} \mathrm{KCL} / \mathrm{ha})$.

Pelaksanaan penelitian terdiri dari beberapa tahapan;

a). Pengolahan tanah. Sebelum pengolahan tanah terlebih dahulu dilakukan pembersihan lahan (land clearing), setelah bersih selanjutnya dilakukan pembajakan dengan traktor untuk memecahkan lapisan tanah menjadi bongkahan-bongkahan dan membalik lapisan tanah kemudian dibiarkan beberapa hari. Selanjutnya tanah digemburkan menjadi struktur yang remah sekaligus membersihkan sisa-sisa perakaran gulma.

b). Pembuatan demplot. Penentuan petak percobaan dalam demplot dilakukan secara 
acak dan disesuaikan dengan kondisi lahan. Luas demplot $414 \mathrm{~m}^{2}$ terdiri dari 15 petak masing-masing berukuran 2,5 × $6 \mathrm{~m}$ dengan jarak antar petak $1 \mathrm{~m}$.

c). Penyiapan stek rumput. Stek rumput diambil dari batang yang sehat, tidak terlalu muda dan tidak terlalu tua, minimal mengandung 2 ruas atau 3 buku, stek dipotong dengan posisi potongan miring sekitar $45^{\circ}$, sehingga mudah ditanam.

d). Penanaman. Dilakukan dengan jarak tanam $90 \times 90 \mathrm{~cm}$ dan jarak tanaman ke tepi lebar dan panjang petak masing-masing 35 $\mathrm{cm}$ dan $30 \mathrm{~cm}$. Stek ditanam dengan posisi miring sekitar $45^{\circ} \mathrm{ke}$ arah timur, dengan kedalaman kurang lebih $15 \mathrm{~cm}$ dari permukaan tanah atau 2 buku dibenamkan dalam tanah dan 1 buku di atas permukaan tanah.

e). Pemupukan. Pemupukan dilakukan sesuai dosis perlakuan pada umur dua minggu setelah penanaman. Pupuk dibenamkan dalam tanah dengan membentuk lingkaran pada setiap rumpun rumput gajah. Kebutuhan pupuk per tanaman dihitung dengan rumus sebagai berikut:

$$
\mathrm{KPT}=\frac{\mathrm{LL}\left(\mathrm{m}^{2}\right)}{10.000 \mathrm{~m}^{2}} \times \mathrm{DPR}(\mathrm{kg} / \mathrm{ha}) / \mathrm{JT}
$$

KPT : kebutuhan pupuk/tanaman,

LL : luas lahan,

DPR : dosis pupuk rekomendasi,

JT : jumlah tanaman

f). Pemeliharaan. Kegiatan pemeliharaan meliputi kegiatan penyiraman yang dilakukan setiap pagi dan sore kecuali pada saat hujan tidak dilakukan. Penyulaman merupakan kegiatan yang dilakukan untuk mengganti tanaman yang mati atau pertumbuhannya kurang baik dalam 2 minggu setelah penanaman. Kegiatan lain yang perlu dilakukan adalah penyiangan, pendangiran yang di lakukan secara bersama-sama, yaitu pembersihan tanaman dari gulma dan penggemburan tanah kembali dengan hati-hati agar tidak merusak sistem perakaran tanaman dan pemupukan. f). Defoliasi. Kegiatan ini dilakukan pada hari ke- 45 setelah tanam, dengan jarak pemotongan $20 \mathrm{~cm}$ dari permukaan tanah. Kemudian rumput di timbang per rumpun dalam setiap petak perlakuan sebagai nilai produksi bahan segar, rasio batang dan daun. g). Analsis sampel. Analisis kandungan bahan kering (BK) dan bahan organik (BO) digunakan sampel sebanyak $200 \mathrm{~g}$ dengan rasio batang dan daun rumput gajah (40:60). Kandungan BK dan BO rumput gajah dianalisis berdasarkan prosedur yang dikemukakan oleh Haris (1970).

Variabel yang akan diamati adalah produksi bahan segar $\left(\mathrm{kg} / \mathrm{m}^{2}\right)$, produksi bahan kering $\left(\mathrm{kg} / \mathrm{m}^{2}\right)$, rasio batang daun $(\%)$ dan kandungan bahan organik dan bahan kering $\left(\mathrm{kg} / \mathrm{m}^{2}\right)$ dari rumput gajah. Data yang diperoleh dianalisis menggunakan analisis varians dari Rancangan Acak Kelompok (RAK), yang dilanjutkan dengan uji Beda Nyata Jujur (BNJ) apabila $\mathrm{P} \geq 0,05$.

\section{HASIL DAN PEMBAHASAN}

Pertumbuhan rumput gajah (Pennisetum purpureum) setelah penanaman dinilai cukup baik, hingga pada saat penyeragaman dan pemupukan sesuai dosis perlakuan. Hal ini di tunjang dengan kondisi iklim selama penelitian yaitu curah hujan cukup tinggi, suhu harian antara 26,00 $39,60^{\circ} \mathrm{C}$, dan kelembaban udara yang cukup tinggi yaitu $80,00-94,00 \%$.

\section{Produksi Bahan Segar}

Hasil analisis varians menunjukkan bahwa dosis pemberian pupuk $\mathrm{N}, \mathrm{P}$, dan $\mathrm{K}$ pada perlakuan 1, 2 dan 3 tidak memberikan pengaruh yang signifikan $(\mathrm{P} \geq 0,05)$ terhadap produksi bahan segar rumput gajah (Pennisetum purpureum) pada defoliasi hari ke-45 setelah tanam.

Walaupun tidak berbeda secara statistik, namun perlakuan 2 dan 3 meningkatkan produksi bahan segar rumput gajah sebesar $29,86 \%$ dari perlakuan 1 (kontrol). Rerata produksi bahan segar rumput gajah disajikan pada Gambar 1. 


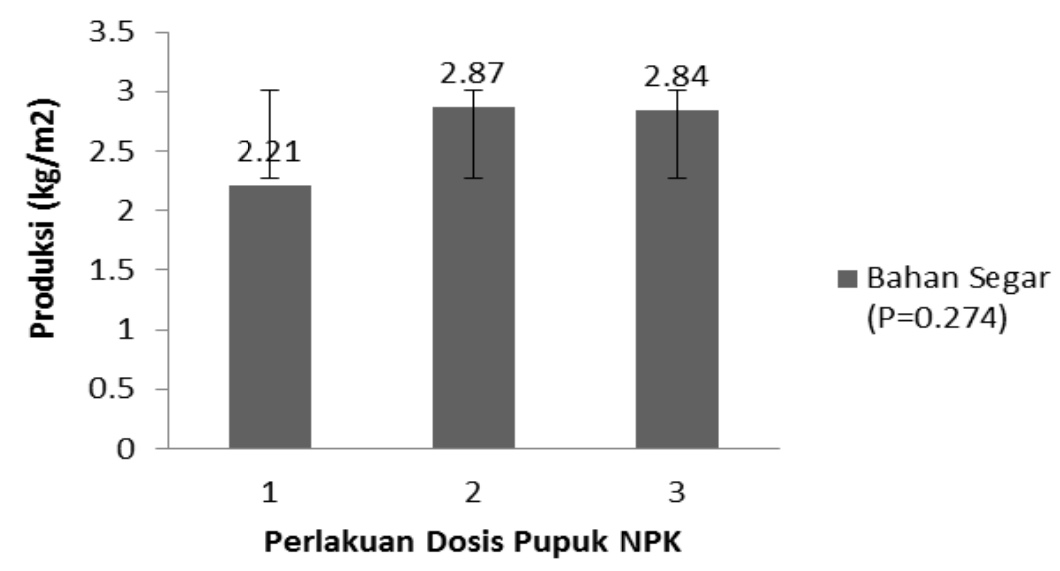

Gambar 1. Rerata Produksi Bahan Segar Rumput Gajah.

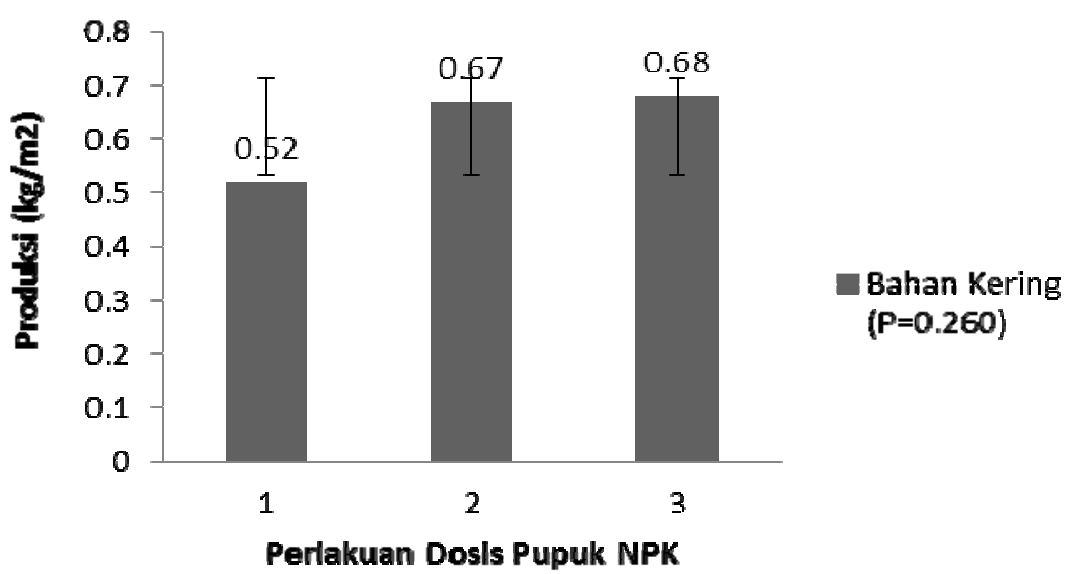

Gambar 2. Rerata Produksi Bahan Kering Rumput Gajah.

Pada penelitian Manauw (2005), menggunakan sistem tiga strata (STS) tanpa pemupukan melaporkan produksi segar rumput gajah $2,14 \mathrm{~kg} / \mathrm{m}^{2}$ dan I-Wayan (1998), dengan pemupukan dosis tinggi 900 $\mathrm{kg} \mathrm{Urea/ha,} 450 \mathrm{~kg} \mathrm{TSP} / \mathrm{ha}, 450 \mathrm{~kg} \mathrm{KCL} / \mathrm{ha}$ produksi segar rumput gajah rata-rata adalah 525 ton/ha/tahun atau $52,5 \mathrm{~kg} / \mathrm{m}^{2} /$ tahun. Menurut Sugandi (1992), rata-rata produksi hijauan segar rumput gajah dengan dosis pupuk $100 \mathrm{~kg}$ Urea/ha, $50 \mathrm{~kg}$ TSP/ha dan 10 ton pupuk kandang adalah $0,27 \mathrm{~kg} / \mathrm{m}^{2}$.

Hasil yang diperoleh pada penelitian ini lebih tinggi dibandingkan penelitian Sugandi (1992) dan Manauw (2005), tetapi masih rendah dibandingkan I-Wayan (1998), ini diduga karena dosis perlakuan pemupukan yang digunakan masih rendah, sehingga perlu dilakukan peningkatan dosis pupuk $\mathrm{N}, \mathrm{P}$, dan $\mathrm{K}$ untuk memperoleh hasil produksi yang optimal.

\section{Produksi Bahan Kering}

Hasil analisis varians menunjukkan bahwa dosis pemberian pupuk N, P, dan K pada perlakuan 1, 2 dan 3 tidak memberikan pengaruh yang signifikan $(\mathrm{P} \geq 0,05)$ terhadap produksi bahan kering rumput gajah pada defoliasi hari ke-45 setelah tanam. Rerata produksi bahan kering rumput gajah disajikan pada Gambar 2.

Rerata produksi bahan kering menunjukkan bahwa perlakuan 2 dan 3 meningkatkan rata-rata produksi bahan kering masing-masing $28,85 \%$ dan $30.77 \%$ 
dibandingkan perlakuan 1 (kontrol). Menurut Siregar (1998) yang disitasi Lugiyo dan Sumarto (2000) dan Rukmana (2005), pada pemupukan berat 40 ton pupuk kandang/ha, Urea $800 \mathrm{~kg} / \mathrm{ha}$, TSP $200 \mathrm{~kg} / \mathrm{ha}$, dan KCL $200 \mathrm{~kg} / \mathrm{ha}$ produksi bahan kering rumput gajah cv Hawaii adalah 63 ton/ha/tahun atau $6,3 \mathrm{~kg} / \mathrm{m}^{2} /$ tahun dan rumput gajah cv Afrika 40 ton/ha/tahun atau $4,0 \mathrm{~kg} / \mathrm{m}^{2} /$ tahun. Sedangkan penelitian ini dengan dosis pemupukan sesuai perlakuan rata-rata produksi bahan kering lebih rendah, hal ini diduga pemberian pupuk yang belum mencukupi kebutuhan unsur hara sehingga menghasilkan produksi bahan kering yang lebih rendah.

\section{Rasio Batang dan Daun}

Rasio batang dan daun rumput gajah yang ditanam pada tanah dengan perlakuan dosis pupuk tertera pada Gambar 3. Hasil analisis varians menunjukkan bahwa dosis pemberian pupuk $\mathrm{N}, \mathrm{P}$, dan $\mathrm{K}$ pada perlakuan 1, 2 dan 3 tidak memberikan pengaruh yang signifikan $(\mathrm{P} \geq 0,05)$ terhadap rasio batang dan daun rumput gajah pada defoliasi hari ke-45 setelah tanam.

Untuk hijauan makanan ternak yang sangat dibutuhkan dari produksinya adalah daun yang dapat dikonsumsi oleh ternak. Berdasarkan Gambar 3 dapat dilihat bahwa rasio daun pada perlakuan 2 lebih tinggi dibanding perlakuan 1 dan 3. Rasio batang daun dalam hijauan segar rumput gajah $\mathrm{cv}$ Hawaii adalah $59: 41$ dan rumput gajah cv Afrika 57 : 43 (Rukmana, 2005). Sedangkan menurut Manauw (2005), persentase daun rumput gajah pada umur 6 minggu adalah $57,94 \%$. Bila dibandingkan dengan penelitian lainnya rasio daun yang dihasilkan dalam penelitian ini relatif rendah. Hal ini diduga karena panen dilakukan pada masa pembungaan (fase generatif) sehingga produksi daun telah menurun. Cepatnya fase generatif rumput gajah ini diduga karena pengaruh pemangkasan yang dilakukan beberapakali akibat gangguan ternak.

\section{Kandungan Bahan Kering dan Organik}

Hasil analisis varians menunjukkan bahwa dosis pemberian pupuk $\mathrm{N}, \mathrm{P}$, dan $\mathrm{K}$ pada perlakuan 1, 2 dan 3 tidak memberikan pengaruh yang signifikan $(\mathrm{P} \geq 0,05)$ terhadap kandungan bahan kering (BK) dan bahan organik (BO). Rerata kandungan kandungan BK dan BO pada defoliasi hari ke-45 setelah tanam dengan berbagai perlakuan dosis pupuk N, P, dan K disajikan pada Gambar 4.

Kandungan BK dan $\mathrm{BO}$ rumput gajah pada penelitian ini lebih tinggi dibandingkan penelitian yang dilakukan Santoso at al. (2007), yaitu masing-masing 19,94\% dan 88,83\% dan Rukmana (2005), yaitu $19,9 \%$ dan $88,3 \%$.

Tingginya kandungan BK yang diperoleh pada penelitian ini diduga karena adanya perbedaan lokasi penanaman, waktu dan iklim saat penanaman hingga panen. Disamping itu juga dapat disebabkan oleh proses pembentukan bunga yang terlalu dini akibat musim penghujan dan perubahan cuaca, sehingga pada umur panen 45 hari tanaman telah mencapai fase generatif. Hal ini sesuai dengan pendapat Beever et al. (2000) disitasi Mansyur et al. (2004), proporsi BK yang dikandung oleh rumput berubah seiring dengan umur tanaman, makin tua tanaman maka akan lebih sedikit kandungan airnya dan proporsi dinding sel lebih tinggi dibandingkan dengan isi sel. Apabila kandungan dinding sel yang dimiliki tanaman lebih besar maka tanaman tersebut akan lebih banyak mengandung BK.

Tingginya kandungan BO yang diperoleh pada perlakuan 3 dibandingkan perlakuan 2 dan 1, diduga karena pengaruh ketersediaan $\mathrm{N}$ dalam tanah yang cukup tinggi, dimana menurut Karieen (2007), N merupakan unsur yang paling banyak terakumulasi dalam BO karena merupakan unsur yang penting dalam sel mikroba yang terlibat dalam proses perombakan BO tanah. Lebih lanjut dikatakan bahwa BO dihasilkan oleh tanaman melalui proses fotosintesis sehingga unsur karbon merupakan penyusun utama dari BO tersebut. 


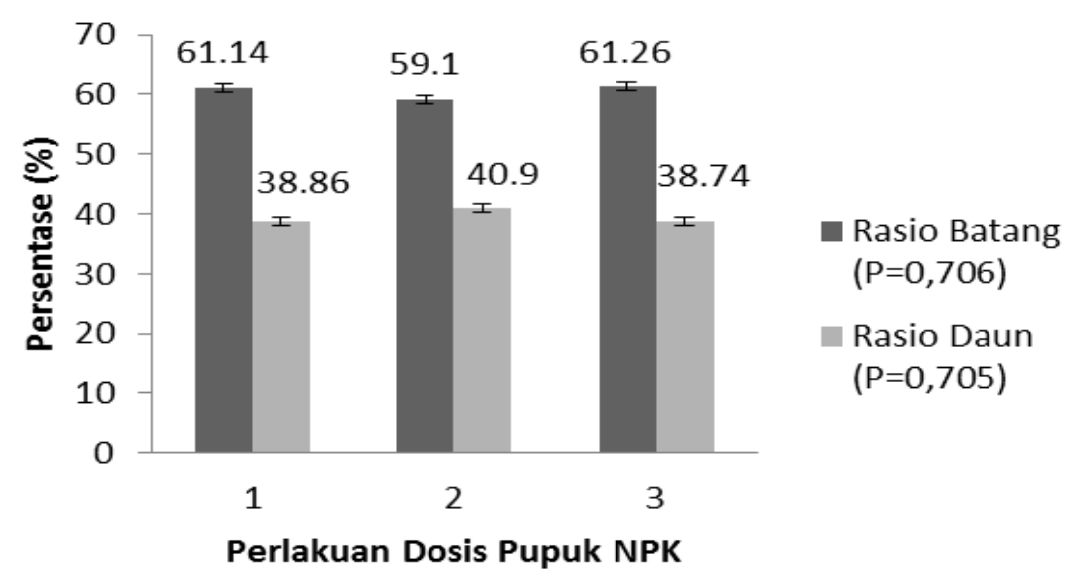

Gambar 3. Persentase Batang dan Daun Rumput Gajah.

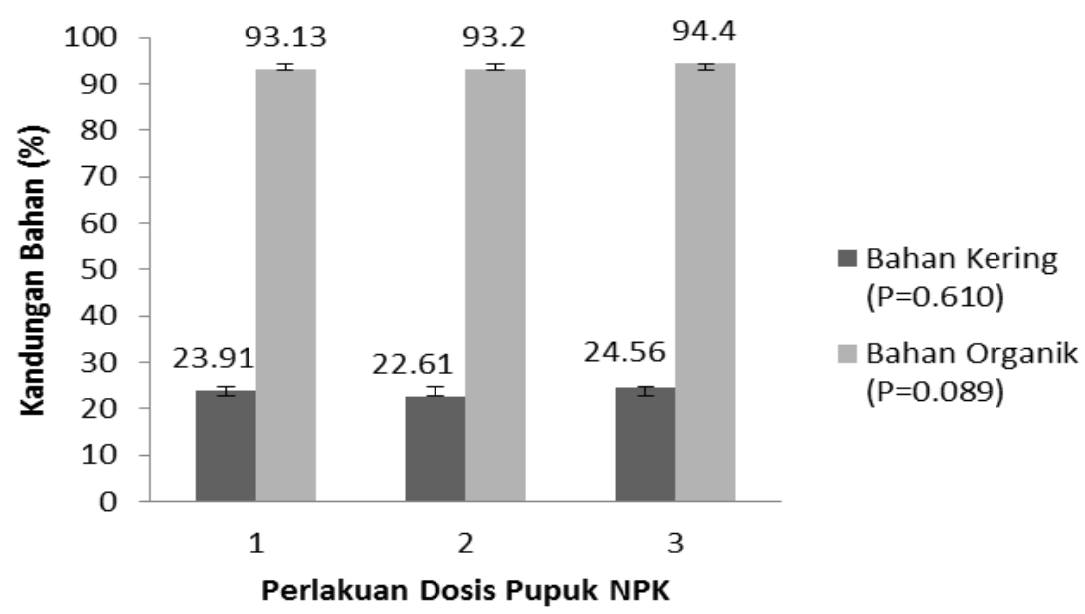

Gambar 4. Rerata Kandungan BK dan BO Rumput Gajah.

\section{KESIMPULAN}

Dosis pemupukan tidak berpengaruh terhadap produksi rumput gajah pada defoliasi hari ke-45. Perlakuan 2 dan 3 meningkatkan produksi hijauan $29,86 \%$ dan $28,51 \%$, dan BK $28,85 \%$ dan $30,77 \%$ dibandingkan kontrol. Rasio batang dan daun rumput gajah bervariasi antara 59,10$61,26 \%$ : 38,70-40,90\%. Kandungan BO cenderung meningkat seiring peningkatan dosis pupuk N, P, dan $\mathrm{K}$.

\section{UCAPAN TERIMA KASIH}

Ucapan terima kasih kepada Ir. A. Gatot Murwanto, M.Si dan Ir. M. Junaidi, M.Si atas bimbingan dan arahan selama pelaksanaan penelitian.

\section{DAFTAR PUSTAKA}

AAK. 1983. Hijauan Makanan Ternak Potong, Kerja dan Perah. Penerbit Kanisius, Yogyakarta.

Adiati, U. Soepeno, E. Handiwirawan, A. Gunawan dan D. Anggraeni. 1995. Pengaruh Pemberian Pupuk Kandang Terhadap Produksi Rumput Gajah (Pennisetum purpureum) di kecamatan Puspo Kabupaten Pasuruan. Prosiding Seminar Nasional Peternakan dan Veteriner, 7 - 8 November di Bogor, Jilid 2 : $583-586$.

Fanindi, A., S. Yuhaini dan A. Wahyu. 2005. Pertumbuhan dan Produktivitas Tanaman Sorgum (Sorghum bicolor L) Moench dan Sorgum sudanense (Piper Stafp) yang Mendapatkan Kombinasi Pemupukan $\mathrm{N}, \mathrm{P}, \mathrm{K}$ dan Ca. Prosiding Seminar Nasional 
Peternakan dan Veteriner, 12 - 13 September di Bogor, Buku 2 : 872 - 885.

Haris, L. E. 1970. Nutrition Research Techniques for Domestic and Wild Animals. Utah State University. Logan, Utah.

I-Wayan, M. 1998. Sekilas Bahan Pakan dan Formulasi Ransum untuk Sapi Potong. Balai Penelitian Ternak, Bogor.

Karieen. 2007. Bahan Organik. http : //Karieen.Wordpress.Com. Diakses 04 Juli 2012.

Lugiyo dan Sumarto. 2000. Teknik Budidaya Rumput Gajah cv Hawaii (Pennisetum purpureum). Prosiding Temu Teknis Fungsional Non Peneliti. Diterbitkan Pusat Penelitian dan Pengembangan Pertanian. Departemen Pertanian : 120 - 125.

Manauw, E. 2005. Pertumbuhan dan Produksi Rumput Gajah (Pennisetum purpureum) pada Sistem Tiga Strata (STS) di Distrik Oransbari Kabupaten Manokwari. Skripsi Sarjana. Fakultas Peternakan Perikanan dan Ilmu Kelautan. Universitas Negeri Papua, Manokwari. (tidak diterbitkan).

Mansyur, S. Hardjosoewignyo dan L. Abdullah. 2004. Respon Rumput Brachiaria humudicola (Rendle) Schweick Terhadap Interval Pemotongan. Jurnal Ilmu Ternak, 4 (2) : $57-61$
Prasetyo, A. 2003. Model Usaha Rumput Gajah Sebagai Pakan Sapi Perah Di Kecamatan Getasan, Kabupaten Semarang. Lokakarya Nasional Tanaman Pakan Ternak. Semarang.

Sajimin, I. P. Kompiang, Supriyati dan N. P. Suratmini. 2001. Penggunaan Biofertilizer untuk Penigkatan Produktifitas Hijauan Pakan Rumput Gajah (Pennisetum purpureum cv Afrika) pada Lahan Marjinal di Subang Jawa Barat. Media Peternakan, $24(2): 46-50$.

Santoso, B., M. N. Lekitoo dan Umiyati. 2007. Komposisi Kimia dan Degradasi Nutrien Silase Rumput Gajah yang Diensilase dengan Residu Daun Teh Hitam. J. Animal Production. 9 (3) : 160 - 165.

Sari, N. K. 2009. Produksi Bioethanol Dari Rumput Gajah Secara Kimia. Jurnal Teknik Kimia, 4 (1) : 265 - 273.

Sirait, J., N. D. Purwantari dan K. Simanihuruk. 2005. Produksi dan Serapan Nitrogen Rumput pada Naungan dan Pemupukan yang Berbeda. Jurnal Ilmu Ternak dan Veteriner, 10 (3) : 175 - 181.

Sugandi, D., U. Kusnadi, M. Sabrani, M.E. Siregar dan D. Muslih. 1992. Budidaya Beberapa Jenis Tanaman Pakan di Lahan Kering Batumarta. Jurnal Ilmu dan Peternakan, 5 (2) : 87 - 91. 